\title{
False-positive 'cord sign'
}

\author{
Praveen Kesav, Vishnu V Y, Ankush Sharma, Dheeraj Khurana
}

Department of Neurology, Post Graduate Institute of Medical Education and Research (PGIMER), Chandigarh, India

\section{Correspondence to} Dr Dheeraj Khurana, dherajk@yahoo.com

\section{DESCRIPTION}

A 26-year-old man with complex cyanotic congenital heart disease (Ostium secundum atrial septal defect with pulmonary and tricuspid atresia) presented with an acute onset of holocranial headache and vomiting. He had conjunctival plethora (figure 1A), central cyanosis and clubbing. Fundus showed no papilloedema. There were no focal neurological deficits. His haemoglobin and haematocrit were $17.5 \mathrm{~g} / \mathrm{dl}$ and $58 \%$, respectively. Chest roentenograph showed a 'boot-shaped heart' (figure 1B). Non-contrast CT scan of head showed hyperdense cortical vein, superior sagittal (figure 1C) and bilateral transverse sinuses ('Cord sign'; figure 1D). Gadolinium-enhanced MR venogram revealed no thrombus (figure1E). Headache subsided with adequate hydration and institution of analgesics (oral paracetamol $650 \mathrm{mg}$ daily for 5 days). 'Cord sign' appears as the result of increased attenuation in either the dural sinuses or a vein filled with thrombus on unenhanced brain CT scan. ${ }^{1}$ False-positive 'cord sign' may occur with elevated haematocrit ${ }^{1}$ (polycythemia, dehydration) as was noted in this patient.

\section{Learning points}

- 'Cord sign' refers to increased attenuation in either dural venous sinuses or a vein filled with thrombus on unenhanced cranial CT.

- Diagnostic utility of 'Cord sign' is hampered by false-positives as in clinical conditions associated with elevated haematocrit.

- 'Cord sign' positivity on CT has to be reconfirmed with gold-standard investigations like MR/CT venography whenever available.

Contributors PK was responsible for data collection, review of literature and drafting of the manuscript. VVY and AS were responsible for data collection. DK was responsible for revision of the manuscript. All the authors approved the final draft of the manuscript.

Competing interests None.

Patient consent Obtained.

Provenance and peer review Not commissioned; externally peer reviewed.

\section{REFERENCE}

1 Vijay RKP. The cord sign. Radiology 2006;240:299-300.
To cite: Kesav $P, \vee Y V_{1}$ Sharma A, et al. BMJ Case Rep Published online:

[please include Day Month Year] doi:10.1136/bcr-2013009557

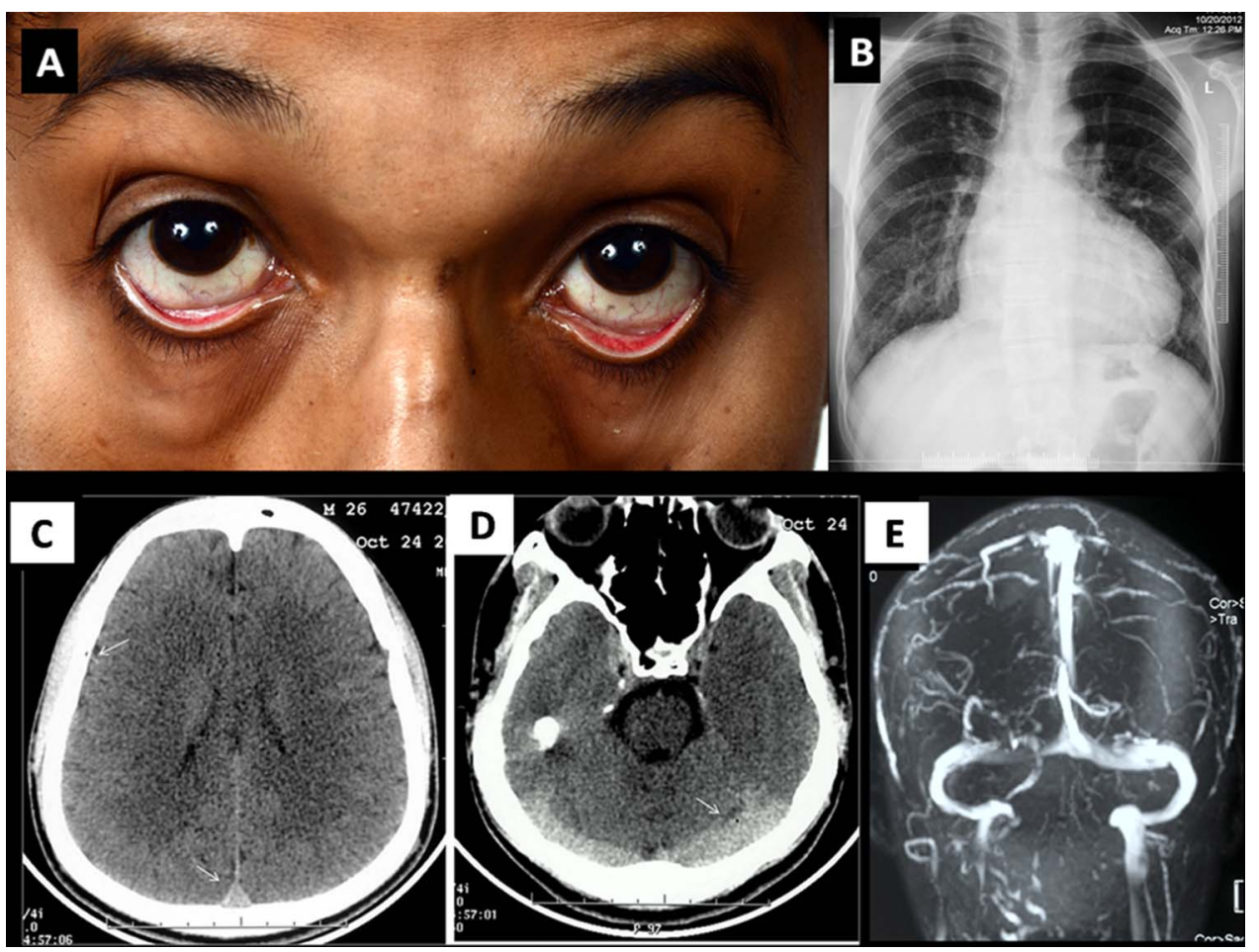

Figure 1 (A) Clinical photograph depicting conjunctival plethora. (B) Chest roentenograph postero/anterior view showing 'boot shaped heart. Non-contrast cranial CT scan showing (C) hyperdensities in cortical vein (arrow), superior sagittal and (D) bilateral transverse sinuses (arrow). (E) Gadolinium-enhanced MR venogram showing clogging of blood in venous sinuses without evidence of acute thrombus. 
Copyright 2013 BMJ Publishing Group. All rights reserved. For permission to reuse any of this content visit http://group.bmj.com/group/rights-licensing/permissions.

BMJ Case Report Fellows may re-use this article for personal use and teaching without any further permission.

Become a Fellow of BMJ Case Reports today and you can:

- Submit as many cases as you like

- Enjoy fast sympathetic peer review and rapid publication of accepted articles

- Access all the published articles

- Re-use any of the published material for personal use and teaching without further permission

For information on Institutional Fellowships contact consortiasales@bmjgroup.com

Visit casereports.bmj.com for more articles like this and to become a Fellow 